\title{
EFFECT OF PHENOBARBITAL ON GROWTH, ADRENOCORTICAL ACTIVITY AND SOME METABOLIC PARAMETERS IN PIGLETS
}

\author{
M. DVOR̆ÁK \\ Veterinary Research Institute, 62132 Brno
}

Received fanuary 29, 1979

\begin{abstract}
Dvořák, M.: Effect of Phenobarbital on Growth, Adrenocortical Activity and some Metabolic Parameters in Piglets. Acta vet. Brno, 48, 1979, 67-77.

Effects of phenobarbital treatment of piglets at 1 to 43 days of age in 4 experiments were manifested only immediately after or during the treatment. Three $\mathrm{i} / \mathrm{m}$ doses of $12 \mathrm{mg} / \mathrm{kg}$ phenobarbital given to piglets at 1,3 and 5 days of age increased relative adrenal mass. Oral administration of phenobarbital to piglets for 14 days after weaning at the mean daily rate of $4 \mathrm{mg} / \mathrm{kg}$ increased liver mass and feed conversion efficiency. A tendency to increased body mass gain in phenobarbital-treated animals was observed particularly in weaned piglets with diarrhoea. Phenobarbital treatment in conjunction with repeated venipuncture increased the production of 17-hydroxycorticosteroids by adrenal tissue in vitro on incubation with adrenocorticotrophic hormone. In all these experiments blood plasma corticosteriod concentration was slightly lower than in untreated controls. Phenobarbital did not affect the levels of total protein, urea, glucose, cholesterol and nonesterified fatty acids in the blood plasma. The changes in these parameters during 14 days after weaning reflect alterations in the internal environment. It was concluded that administration of phenobarbital to piglets may increase their adrenocortical function, but that this rise is not manifested by an increase in blood plasma corticosteroids in consequence of increased hepatic microsomal metabolizing activity. Under the conditions used, injection of phenobarbital into piglets during the neonatal period had no late effects on any of the parameters under study. The possibility of increasing the performance of pigs by using phenobarbital in preparing medicated feed for weaned piglets is discussed.
\end{abstract}

Psychopharmacological drugs, neonatal stimulation, corticosteroids, liver, body mass, pig.

Phenobarbital, a well-known long-acting hypnotic, is presently little used in veterinary medicine apart from being fed as a sedative to poultry. On the other hand, it has found wide application in pediatrics (Boréus et al. 1975) and has received considerable attention in molecular biology ( $\mathrm{S} \mathrm{mith}$ et al. 1976). It stimulates the activity of various liver microsomal enzymes including drugmetabolizing enzymes (Kuenzig et al. 1975), thus altering the duration and intensity of drug action. Its inductive effect on bilirubin glucuronyl-transferase to lower plasma bilirubin levels (David and Yeary 1975) has been utilized in the treatment of neonatal jaundice. Enzyme systems in liver microsomes also hydroxylate or glucuronize steroids including cortisol (Conney et al. 1973). Studies on the effects of phenobarbital demonstrated a decrease in blood corticosteroids (Takahashi et al. 1971; Raszyk and Dvořák 1976), inhibition of cholesterol synthesis (Kritchevsky et al. 1976) and intestinal absorption of cholesterol (Byers and Friedman (1976). Phenobarbital also affects the metabolism of carbohydrate (Schaub and Friedrich-Freksa 1976), protein (Flint and Richardson 1974; Ragnotti and Aletti 1975) and iron (Thomas et al. 1972).

The bulk of the effects mentioned above was demonstrated only in laboratory animals and, for the most part, in vitro. In farm animals a few isolated studies have been made to explain the possibility of using phenobarbital for degradation of foreign substances (Bennink et al. 1973; Ferrando et al. 1974). No data to this effect are available in pigs, even though it has been established that the postnatal development of the pig is characterized by a low activity of microsomal drug- 
-metabolizing enzymes (Short et al. 1972). An analogous situation exists in some other animal species. Treatment of pregnant guinea-pigs with phenobarbital increased this activity in the foetuses and altered the ultrastructural appearance of their hepatic smooth endoplasmic reticulum (Kuenzig et al. 1975).

The foregoing observations including the possibility that phenobarbital affects substance metabolism particularly by its effects on some hepatic functions prompted us to investigate in the present study the effects of repeated phenobarbital administration to suckling and weaned piglets on their growth rate expressed in terms of body and liver mass, blood plasma levels of nutrient metabolites and on adrenocortical function. Since the possibility cannot be excluded that administration. of phenobarbital to newborn pigs changes their steroid hormone levels, a phenomenon which may have late effects, the development of the aforementioned parameters was also followed for an extended period of time in piglets treated with a single dose of phenobarbital at 1 to 2 days of age.

\section{Materials and Methods}

Four groups of Large White piglets reared conventionally in the Institute in bedded pens and weaned at 4 weeks of age were employed. They had free access to water and were given a commercial prestarter (COS 1) and a commercial starter (ČOS 2). All piglets, except Group 1, were treated $\mathrm{i} / \mathrm{m}$ with Ferridextran (SPOFA) to prevent anaemia. Blood samples were taken from the cranial vena cava. All blood collections, weighing, injections as well as exsanguinations by decapitation. were carried out invariably between 7 and $8 \mathrm{a} . \mathrm{m}$. without previous food deprivation.

Group 1 comprised 16 male piglets from 3 litters. Eight piglets were inoculated intramuscularly with Phenobarbital SPOFA (acidum 5-aethyl-5-phenyl-barbituricum) at the rate of $12 \mathrm{mg} / \mathrm{kg}$ body mass at 1, 3 and 4 days of age. The remaining 8 animals were sham-inoculated with saline to serve as controls. Peripheral blood samples for determination of eosinophile granulocyte counts were withdrawn 3 and 6 hours after the last treatment. All piglets were exsanguinated 24 hours later.

Group 2 comprised 20 piglets from 3 litters. After the piglets were weaned at an average of 27 days after birth, half of each litter received feed containing phenobarbital at $100 \mathrm{mg} / \mathrm{kg}$ for 14 days and the other half of each litter with the same sex distribution was given nonmedicated feed. Nine experimental piglets and 9 controls were exsanguinated at an average of 41 days of age.

Group 3 comprising 24 piglets from 3 litters was used to repeat the previous experiment except that all animals were blood-sampled five times at 2-to 5-day intervals starting at weaning at an average of 29 days of age. The last blood collection was made 14 days after the start of the experiment, at which time 8 experimental piglets and 8 controls were exsanguinated.

Group 4 comprised 11 experimental piglets and 11 controls from litters matched for body mass and sex. The experimental animals were treated $\mathrm{i} / \mathrm{m}$ with a single dose of Phenobarbital SPOFA at 1 to 2 days af age using the following doses in the 4 litters: $10 \mathrm{mg}(0.1 \mathrm{ml}), 12 \mathrm{mg}, 12 \mathrm{mg}$ and $15 \mathrm{mg}$ per $\mathrm{kg}$ body mass. All piglets were tattooed at this time. They were weighed at regular intervals, were weaned at 4 weeks of age and were blood-sampled at the time of weaning and then 14 days later, at which time 8 experimental and 8 controls were killed.

In addition to checks on the clinical state ang gain in body mass, determinations were made of blood plasma 17-hydroxycorticosteroids (17-OHCS), total protein, urea, glucose, nonesterified fatty acids (NEFA) and cholesterol. In some cases eosinophile granulocytes counts were made in blood samples withdrawn from the ear vein. After the piglets were killed, determination was made of their liver and adrenal mass and of the production of 17-OHCS by adrenal slices in vitro on incubation with adrenocorticotrophic hormone (ACTH). The methods used were described in previous reports (Dvořák 1975, 1979). The results are tabulated as arithmetic means \pm standard deviations and are shown graphically as means \pm standard errors of the means. The significance of the differences of the means was assessed by Student's t-test.

\section{Results}

Intramuscular administration of phenobarbital to Group 1 piglets at 1,3 and 4 days of age did not produce distinct clinical changes and did not affect either their inclination to suck or their growth expressed in terms of body mass (Table 1). Three and 6 hours after the last treatment the level of circulating eosinophile granulocytes was 27 per cent lower in the experimental animals and 72 and 16 per cent lower, respectively, in the controls. Twenty-four hours after the last treatment eosinophile granulocyte counts were still slightly higher and, in keeping with this, the concentration of 17-OHCS in blood plasma non-significantly 
Table 1

Body mass, liver mass and parameters of adrenocortical function and substance metabolism in 5-day-old piglets after three $\mathbf{i} / \mathbf{m}$ doses of phenobarbital

\begin{tabular}{|c|c|c|}
\hline \multirow{2}{*}{ No. of piglets } & Phenobarbital & Control \\
\hline & 8 & 8 \\
\hline $\begin{array}{l}\text { Body mass }(\mathrm{kg}) \\
1 \text { day after birth } \\
3 \text { days after birth } \\
5 \text { days after birth } \\
\text { Body mass gain during days } 1-3 \\
\text { Body mass gain during days } 1-5 \\
\text { Liver mass } \\
\text { actual }(\mathrm{g}) \\
\text { relative }(\mathrm{g} / \mathrm{kg}) \\
\text { Adrenal mass } \\
\text { actual }(\mathrm{mg}) \\
\text { relative }(\mathrm{mg} / \mathrm{kg}) \\
\text { Production of } 17-\mathrm{OHCS} \text { in vitro } \\
(\mu \mathrm{g} \text { per } 100 \mathrm{mg} \text { adrenal tissue } \\
\text { Plasma } 17-\mathrm{OHCS}(\mathrm{nmol} / \mathrm{l}) \\
\text { Eosinophile granulocytes }\left(\times 10^{\circ} / 1\right) \\
\text { Plasma glucose }(\mathrm{mmol} / \mathrm{l}) \\
\text { Plasma total protein }(\mathrm{g} / \mathrm{l}) \\
\text { Plasma urea }(\mathrm{mmol} / \mathrm{l}) \\
\text { Plasma cholesterol }(\mathrm{mmol} / \mathrm{l}) \\
\text { Plasma NEFA }(\mu \mathrm{mol} / \mathrm{l})\end{array}$ & $\begin{array}{l}1.43 \pm 0.26 \\
1.92 \pm 0.39 \\
2.36 \pm 0.42 \\
0.49 \pm 0.16 \\
0.93 \pm 0.21 \\
82.1 \pm 14.0 \\
34.9 \pm 4.7 \\
411 \pm 48 \\
174 \pm 17 \\
24.6 \pm 4.8 \\
475 \pm 130 \\
11 \pm 9 \\
6.01 \pm 0.47 \\
64.7 \pm 10.0 \\
4.47 \pm 0.73 \\
3.96 \pm 0.45 \\
175 \pm 90\end{array}$ & $\begin{array}{l}1.47 \pm 0.24 \\
1.94 \pm 0.37 \\
2.43 \pm 0.44 \\
0.47 \pm 0.15 \\
0.96 \pm 0.22 \\
81.6 \pm 15.8 \\
33.6 \pm 3.4 \\
363 \pm 64 \\
149 \pm 24 b \\
20.9 \pm 4.7 \\
533 \pm 119 \\
8 \pm 9 \\
6.17 \pm 0.36 \\
65.0 \pm 7.5 \\
4.04 \pm 0.38 \\
4.15 \pm 0.56 \\
164 \pm 95\end{array}$ \\
\hline
\end{tabular}

b Difference between the means significant $(P<0.05)$.

Table 2

Body mass, liver mass and parameters of adrenocortical function and substance metabolism in piglets fed phenobarbital for 14 days after weaning

\begin{tabular}{|c|c|c|}
\hline \multirow{2}{*}{ No. of piglets } & Phenobarbital & Control \\
\hline & 10 & 10 \\
\hline $\begin{array}{l}\text { Body mass }(\mathrm{kg}) \\
7 \text { days before weaning } \\
\text { at weaning } \\
7 \text { days after weaning } \\
14 \text { days after weaning } \\
\text { Body mass gain after weaning } \\
\text { Liver mass } \\
\text { actual }(\mathrm{g}) \\
\text { relative }(\mathrm{g} / \mathrm{kg}) \\
\text { Adrenal mass } \\
\text { actual }(\mathrm{mg}) \\
\text { relative }(\mathrm{mg} / \mathrm{kg}) \\
\text { Production of } 17-\mathrm{OHCS} \text { in vitro } \\
\text { ( } \mu \text { g per } 100 \mathrm{mg} \text { adrenal tissue) } \\
\text { Plasma 17-OHCS }(\mathrm{nmol} / \mathrm{l}) \\
\text { Eosinophile granulocytes }\left(\times 10^{8} /\right) \\
\text { Plasma glucose }(\mathrm{mmol} / \mathrm{l}) \\
\text { Plasma cholesterol }(\mathrm{mmol} / \mathrm{l})\end{array}$ & $\begin{array}{c}5.92 \pm 1.20 \\
7.65 \pm 1.34 \\
7.61 \pm 1.41 \\
9.13 \pm 1.53 \\
1.48 \pm 0.60 \\
277 \pm 55 \\
30.4 \pm 3.5 \\
743 \pm 171 \\
83.8 \pm 21.1 \\
12.9 \pm 3.8 \\
235 \pm 58 \\
61 \pm 33 \\
4.10 \pm 0.67 \\
2.56 \pm 0.41\end{array}$ & $\begin{aligned} 5.95 & \pm 1.42 \\
7.61 & \pm 1.66 \\
7.35 & \pm 1.82 \\
8.46 \pm & \pm .13 \\
0.85 & \pm 0.91 \\
& \\
214 & \pm 54 \mathrm{~b} \\
26.2 & \pm 2.8 \mathrm{a} \\
757 & \pm 185 \\
96.9 & \pm 30.8 \\
10.6 & \pm 2.6 \\
284 & \pm 61 \\
75 & \pm 40 \\
4.09 & \pm 0.62 \\
2.66 & \pm 0.51\end{aligned}$ \\
\hline
\end{tabular}

a Difference between the means highly significant $(P<0.01)$.

b Difference between the means significant $(P<0.05)$

lower in the experimental animals than in the controls. On the other hand, an increase in relative adrenal mass found in piglets exsanguinated at 5 days of age suggests that the adrenocortical activity of phenobarbital-treated piglets was increased. In keeping with this, the production of 17-OHCS by adrenal tissue in vitro tended to increase and liver mass was slightly enhanced as against the controls. Slight differences between the experimental and control animals were found in the concentration of glucose, total protein, urea, cholesterol and NEFA in the blood plasma (Table 1). 

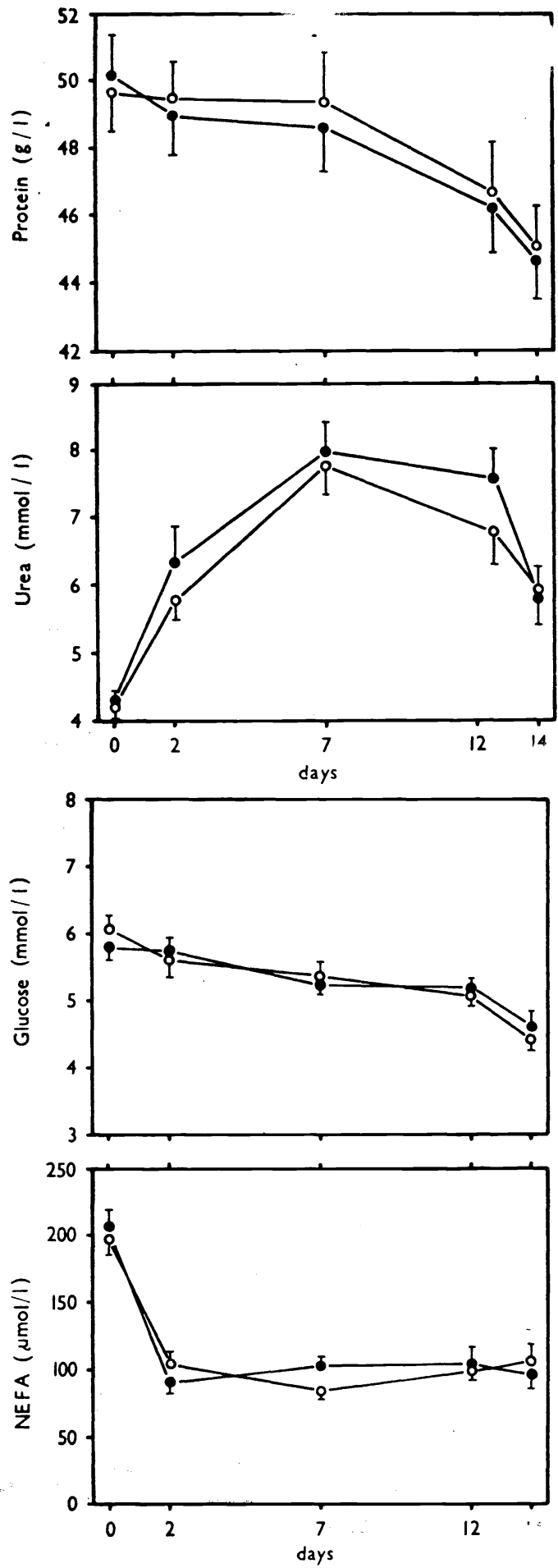

Fig. 1.

Total protein and urea concentrations in the blood plasma of phenobarbitalfed (closed circles) and control (open circles) piglets during 14 days after weaning (Experiment 3)

Phenobarbital added to complete starter and fed to experimental piglets in Group 2 for 14 days after weaning did not affect either the behaviour or the appetite of the animals. Both experimental and control piglets showed mild signs of gastroenteritis with reduced food intake and a temporary reduction in body mass. Total gain in body mass was greater in experimental animals than in the controls, with the difference bordering on significance (Table 2). Feed consumption did not increase until the second week of the observation period, during which time it was markedly higher in experimental piglets than in the controls. Total feed consumption per experimental and control piglet was 4.94 and $4.02 \mathrm{~kg}$ respectively; feed consumption per $\mathrm{kg}$ gain was 3.35 and $4.73 \mathrm{~kg}$, respectively, Total intake of phenobarbital per experimental animal during 14 days was $494 \mathrm{mg}$, i. e. about $35 \mathrm{mg}$ per animal per day and about $4 \mathrm{mg}$ per $\mathrm{kg}$ body mass.

Post-mortem examination in Group 2 revealed significant differences between the experimental and control piglets only in actual and relative liver mass. The adrenocortical activity of the experimental animals was characterized by a slightly enhanced production

Fig. 2.

Glucose and nonesterified fatty acid concentrations in the blood plasma of phenobarbital-fed (closed circles) and control (open circles) during 14 days after weaning (Experiment 3 ) 
of 17-OHCS by adrenal tissue in vitro and their slightly lowered concentration in the blood plasma. There were no substantial differences in the concentration of the metabolites under study (Table 2).

In Group 3 where feeding of phenobarbital to experimental piglets in complete starter was combined with blood collections from all animals of this group at and $2,7,12$ and 14 days after weaning no distinct differences were observed in the behaviour of experimental and control animals. The growth rate of both phenobarbital-fed and control piglets, expressed in terms of body mass, was good except for a temporary cessation during the first two days after weaning and tended to rise in the 2nd week (Table 3). Growth performance expressed in terms of body mass gain, total feed consumption and feed consumption per $\mathrm{kg}$ gain during 14 days after weaning was better in the experimental animals than in the controls $(2.63 \mathrm{~kg}, 4.80 \mathrm{~kg}$ and $1.88 \mathrm{~kg} / \mathrm{kg}$ vs. $2.48 \mathrm{~kg}, 5.13 \mathrm{~kg}$ and $2.11 \mathrm{~kg} / \mathrm{kg})$. Repeated examination for the concentration of the main nutrient metabolites in the blood plasma did not show significant differences between phenobarbital-fed and control piglets. The pattern of change during 14 days after weaning was essentially the same in experimental and control animals. The levels of glucose, total protein and cholesterol decreased steadily, whereas the level of NEFA fell abruptly within 2 days of weaning (Fig. 1 and 2). Most change was shown by the concentration of urea which rose rapidly and considerably in the first week and declined thereafter (Fig. 1). All the values recorded 14 days after weaning were significantly different $(P<0.01$ or 0.05$)$ from those found at weaning.

Total intake of phenobarbital per experimental piglet during 14 days in Group 3 was $480 \mathrm{mg}$, i. e. about $34 \mathrm{mg}$ per animal per day and about $4 \mathrm{mg}$ per kg body mass. Its effect was manifested by an increase in relative liver mass. The production of 17-OHCS by adrenal tissue in vitro was also significantly $(P<0.05)$ enhanced whereas their concentration in the blood plasma was slightly lower than in the controls (Table 3).

Experimental piglets of Group 4 treated $\mathrm{i} / \mathrm{m}$ with a single dose of phenobarbi-

Table 3

Body mass, liver mass and parameters of adrenocortical function in piglets fed phenobarbital for 14 day after weaning and blood-sampled five times during this period

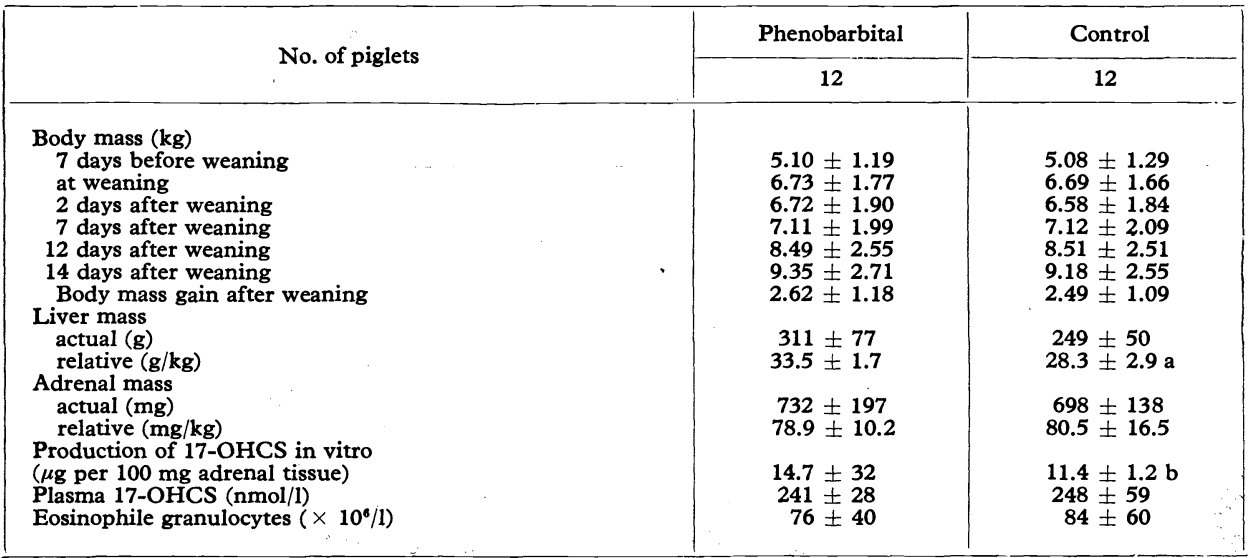

a Difference between the means highly significant $(P<0.01)$.

b Difference between the means significant $(P<0,05)$. 
tal at 1 to 2 days of age did not differ distinctly from the controls. No differences were found among experimental animals in dependence on the dose administered. The growth rate of experimental piglets expressed in terms of body mass was slightly worse than in the controls from the 5th day after birth, but the difference evened out after weaning (Table 4). Not even the parameters of substance metabolism determined at weaning and 14 days later showed any lasting effects of phenobarbital administration during neonatal life. The results confirmed a significant $(P<0.05)$ increase in urea concentration and a significant $(P<0.01$ or 0.05 ) decrease in the remaining metabolites in the blood plasma after weaning as were seen in Group 3. After exsanguination at an average of 42 days of age no differences were found between the experimental and control animals in liver mass and adrenocortical activity. On the other hand, adrenal mass, the concentration of 17-OHCS in blood plasma and their production by adrenal tissue in vitro were slightly higher in phenobarbital-treated animals than in the controls (Table 4).

\section{Table 4}

Body mass, liver mass and parameters of adrenocortical function and substance metabolism in 6-week-old piglets treated with a single $i / m$ dose of phenobarbital at 1 to 2 days of age

\begin{tabular}{|c|c|c|}
\hline \multirow{2}{*}{ No. of piglets } & Phenobarbital & Control \\
\hline & 11 & 11 \\
\hline $\begin{array}{l}\text { Body mass }(\mathrm{kg}) \\
1-2 \text { days after birth } \\
5 \text { days after birth } \\
14 \text { days after birth } \\
21 \text { days after birth } \\
\text { at weaning } \\
14 \text { days after weaning } \\
\text { Body mass gain to weaning } \\
\text { Body mass gain after weaning } \\
\text { Liver mass } \\
\text { actual }(\mathrm{g}) \\
\text { relative }(\mathrm{g} / \mathrm{kg}) \\
\text { Adrenal mass } \\
\text { actual }(\mathrm{mg}) \\
\text { relative }(\mathrm{mg} / \mathrm{kg}) \\
\text { Production of } 17-\mathrm{OHCS} \text { in vitru } \\
(\mu \mathrm{g} \text { per } 100 \mathrm{mg} \text { adrenal tissue }) \\
\text { Plasma } 17-\mathrm{OHCS}(\mathrm{nmol} / \mathrm{l}) \\
\text { Eosinophile granulocytes }\left(\times 10^{8} / 1\right) \\
\text { Plasma glucose }(\mathrm{mmol} / \mathrm{l}) \\
\text { Plasma total protein }(\mathrm{g} / \mathrm{l}) \\
\text { Plasma urea }(\mathrm{mmol} / \mathrm{l}) \\
\text { Plasma cholesterol }(\mathrm{mmol} / 1) \\
\text { Plasma NEFA }(\mu \mathrm{mol} / \mathrm{l})\end{array}$ & $\begin{array}{c}1.40 \pm 0.20 \\
1.83 \pm 0.36 \\
3.45 \pm 0.92 \\
4.93 \pm 1.44 \\
6.59 \pm 1.83 \\
9.05 \pm 2.34 \\
5.19 \pm 1.82 \\
2.44 \pm 0.87 \\
341 \pm 123 \\
32.0 \pm 3.0 \\
740 \pm 255 \\
79.5 \pm 11.8 \\
12.4 \pm 3.8 \\
279 \pm 80 \\
115 \pm 21 \\
4.95 \pm 1.00 \\
47.5 \pm 3.2 \\
5.68 \pm 1.39 \\
2.53 \pm 0.34 \\
97 \pm 37\end{array}$ & $\begin{array}{c}1.40 \pm 0.15 \\
1.85 \pm 0.28 \\
3.72 \pm 0.71 \\
5.26 \pm 1.01 \\
6.95 \pm 1.37 \\
9.34 \pm 1.64 \\
5.55 \pm 1.39 \\
2.38 \pm 0.53 \\
321 \pm 45 \\
31.7 \pm 2.8 \\
734 \pm 170 \\
72.6 \pm 14.0 \\
11.5 \pm 2.2 \\
268 \pm 63 \\
108 \pm 36 \\
5.06 \pm 0.89 \\
47.4 \pm 2.9 \\
5.56 \pm 0.77 \\
2.37 \pm 0.36 \\
76 \pm 26\end{array}$ \\
\hline
\end{tabular}

\section{Discussion}

The present study on suckling and weaned piglets demonstrated some of the effects ascribed to phenobarbital and suggested a number of others. The dosage of phenobarbital employed for intramuscular and oral administration was rather high relative to the rates recommended by the manufacturers for man. However, its sedative effect was not apparent, even though the possibility cannot be excluded that sleep between feed intakes became deeper. It can be assumed that the action of phenobarbital is prolonged also in pigs. Its concentration in the blood plasma of children after an $\mathrm{i} / \mathrm{m}$ dose of 6 or $9 \mathrm{mg} / \mathrm{kg}$ reaches a peak within 2 hours and continues at approximately the same level for at least 12 hours; in 
the prevention of hyperbilirubinaemia a high level of phenobarbital in the blood plasma of newborn children can be maintained by an oral dose of $5 \mathrm{mg} / \mathrm{kg}$ once a day (Boréus et al. 1975). In experimental work phenobarbital is generally used in higher doses. Thus, e. g., an intraperitoneal dose of $100 \mathrm{mg} / \mathrm{kg}$ administered to rats produced steatosis of the liver in as few as 3 days (Tu ma et al. 1974). In 17-to 30-day-old piglets a single oral dose of $10 \mathrm{mg} / \mathrm{kg}$ was sufficient to reduce plasma corticosteroid level in 2 hours (Raszyk and Dvořák 1976).

The action of phenobarbital in experimental piglets is evidenced by the finding that the liver of piglets fed a mean daily dose of $4 \mathrm{mg} / \mathrm{kg}$ body mass for 14 days was enlarged without apparent pathoanatomical changes. In newborn piglets receiving higher doses and killed after a shorter period of time this effect was only suggested. Hepatomegalic action of phenobarbital in laboratory animals was repeatedly demonstrated (Kritchevsky et al. 1976; Erdösová et al. 1977), together with an increased content of hepatic lipids (Tuma et al. 1974). The concentration of liver glycogen in adult rats treated with phenobarbital was reduced (Japundzić et al. 1969). Apparently the mechanisms involved were other than those operating in ACTH-induced increase of liver mass which occurs in weaned and newborn piglets (Dvořák 1974) as the consequence of prolonged gluconeogenetic action of cortisol resulting in increased hepatic glycogen stores.

The enlargement of the liver induced by phenobarbital is presumably associated with enhanced metabolic activity as indicated by a moderate rise in body mass gains and the improved efficiency of feed utilization. It is of interest that experimental piglets from litters that had brief diarrhoea after weaning gained 74 per cent more in body mass than piglets with more or less normal growth in Group 3. It appears possible that phenobarbital also had a beneficial effect on the structure and function of the small intestine (Thomas et al. 1972) and thus ameliorated malabsorption associated with diarrhoea (Rosenberg et al. 1977) and/or reduced the effects of microbial toxic metabolites by its beneficial influence on the detoxication capacity of microsomes. A similar growth-promoting effect of phenobarbital was found in ducklings fed a ration containing aflatoxin (Ferrando et al. 1974). Also the finding of a 12 per cent decreased feed consumption per $\mathrm{kg}$ body mass gain in Group 3 is worthy of note, even though no valid generalization is possible, since the phenomenon may have been due to sedative action of phenobarbital in the stress produced by venepuncture. No growth-promoting effect of phenobarbital was found in rats (Kritchevsky et al. 1976; Erdösová et al. 1977).

Although the beneficial effects of phenobarbital on growth performance of the experimental animals were evident, the effect on the indicators of substance metabolism was not manifested by changes in the blood plasma levels of the main nutrient metabolites including urea in which lower levels could be expected if the utilization of feed proteins were improved. The effects ascribed to phenobarbital in the literature were found, for the most part, in the liver. As to blood serum, attention has been paid mainly to cholesterol, the level of which was lowered by phenobarbital in experimentally induced hypercholesterolaemia (Byers and Friedman 1976). Such action was suggested in our experimental suckling piglets as compared with a physiologically high cholesterol concentration in the controls. In piglets treated with phenobarbital after weaning cholesterol concentration decreased similarly to that found in untreated animals (Dvořák 1967, 1979). Phenobarbital treatment in the present study had no significant effect on the metabolites under study in any of the four groups. Repeated determination of the metabolite levels during 14 days after weaning extended our previous observations 
(Dvořák 1979) by evidence on the progress of changes associated with the transition of piglets from high-lipid breast feeding to a predominantly carbohydrate diet. It showed that the nadir of the NEFA was reached within the first two days, whereas hypocholesterolaemia occurred later. Also the blood plasma level of urea rose considerably shortly after weaning, thus suggesting depressed protein synthesis, and declined during the 2 nd week, which is obviously in keeping with progressive adaptation of the animals and increased gain in body mass.

Adrenocortical activity of the phenobarbital-treated piglets as assessed by evaluation of their adrenal mass and the production of 17-OHCS by adrenal tissue in vitro was, for the most part, enhanced. On the other hand, the concentration of 17-OHCS in the blood plasma of experimental piglets was reduced in the first three groups as against the controls, but the difference was not significant. In contrast, administration of phenobarbital to 4-day-old rats was followed by a rise in corticosterone concentration which was accounted for by low metabolizing activity of the liver at this age (Erdösová et al. 1977). That the circulating eosinophile granulocyte counts of the experimental piglets were not always in keeping with the corticosteroid level can be explained by the fact that newborn piglets have low eosinophil counts in general. In a previous study phenobarbital administered $\mathrm{i} / \mathrm{m}$ to older pigs at $5 \mathrm{mg} / \mathrm{kg}$ body mass did not produce a significant decrease in eosinophile granulocyte counts at 2 or 4 hours in contrast to other psychopharmacological drugs and even saline (Dvořák and Raszyk 1975). Summarizing the results of our studies on phenobarbital effects in piglets it can be said that under the conditions used intramuscular and presumably also oral administration of phenobarbital can stimulate the hypothalamic-pituitary-adrenal axis to increased activity or at least does not prevent this acitivity from being enhanced, but it reduces corticosteroid level in the blood. The resultant effect can presumably be ascribed to induction of microsomal enzymes mainly in hepatic endoplasmic reticulum and to increased inactivation of steroid hormones.

Phenobarbital treatment of piglets at 1,3 and 4 days of age did not affect the levels of any of the indicators under study except adrenocortical function when evaluated 24 hours after the last injection. In the light of the observations on late effects of neonatal stimulation by various hadlings and of enhancement of adrenocortical function in the young of laboratory animals (Levine 1960; Denenberg and Zarrow 1970) it became of interest to find whether this approach could be used to promote the growth rate of the pig. However, the results of our experiments on phenobarbital administration to neonatal pigs provided no evidence to support this view. There were no significant differences in any of the indicators under study between phenobarbital-treated and control piglets from four litters either at weaning or 14 days later. This implies that if alterations were produced by the treatment, they were reversible and had no detectable lasting effects, either beneficial or adverse.

Phenobarbital may also have acted indirectly by influencing adrenocortical function and the central nervous system. It can be admitted that phenobarbital given to piglets in the first days after birth when the activity of drug-metabolizing microsomal enzymes is still low (Short et al. 1972) may produce a temporary rise in circulating corticosteroid level as suggested by increased relative adrenal mass in experimental suckling piglets. This would indicate the operation of mechanism similar to those responsible for the acceleration of body growth and emotional as well as adrenocortical reactivity in rats stimulated merely by handling. Alternatively, phenobarbital might alleviate the effects of simultaneous handling 
of newborn pigs including tattooing which proved stimulatory in untreated controls. Similar observations were reported for rats where treatment with diazepam during infancy exerted an effect on corticosterone regulation and androgenic activity in adult male rats (Erdös ová et al. 1975). Some evidence in support of this alternative might be seen in the finding of a slightly higher average gain in body mass in piglets not treated with phenobarbital. However, it is not possible to exclude other explanations. However, the basic question still remains whether the effects of stimulation of newborn pigs are similar at all to those seen in rats. Conclusive evidence in this respect is lacking.

In evaluating the effects of phenobarbital in pigs only its immediate action can therefore be considered. The results suggest that administration of phenobarbital to piglets may prove of practical value, particularly at weaning, through its beneficial effects on the parameters of feed efficiency. Phenobarbital could be used in combination with suitable tranquilizers in the preparation of medicated feed to quiet piglets at weaning, allottment to groups and during transport. Of equal value might be the utilization of phenobarbital effects for detoxication of contaminated feeds.

\section{Účinek fenobarbitalu na tělesný růst selat, adrenokortikální aktivitu a některé metabolické parametry}

Účinek fenobarbitalu, sledovaný ve 4 pokusech u selat starých $1-43$ dní, se projevil pouze bezprostredně po nebo při jeho podávání. Trojí intramuskulární aplikace v dávce $12 \mathrm{mg} / \mathrm{kg}$ ve stáří 1,3 a 5 dní zvýšila relativní hmotnost nadledvin. Perorální prŕijem po dobu 14 dní po odstavu selat od prasnice $v$ průměrné denní dávce $4 \mathrm{mg} / \mathrm{kg}$ zvýšil hmotnost jater a využitelnost krmiva. Fenobarbital jevil trend ke zvýšení přírůstků tělesné hmotnosti zejména $u$ odstavených selat postižených průjmovým onemocněním. Při opakovaných vénepunkcích zvýšil produkci 17-hydroxykortikosteroidů in vitro při stimulaci s ACTH. Ve všech těchto pokusech byla poněkud nižši koncentrace kortikosteroidů v krevní plazmě. Fenobarbital neovlivnil hladinu celkového proteinu, močoviny, glukózy, cholesterolu nebo neesterifikovaných mastných kyselin $\mathrm{v}$ krevní plazmě. Dynamika změn těchto parametrů v průběhu 14 dní po odstavu charakterizuje závažné změny vnitřního prostředí selat. Fenobarbital asi může působit přechodné zvýšení funkce kůry nadledvin, což se však neprojeví zvýšením hormonálni hladiny $\mathrm{v}$ krvi $\mathrm{v}$ dùsledku zvýšené metabolizující aktivity hepatocytů. Parenterální podání fenobarbitalu $\mathrm{v}$ neonatálním údobí se za daných podmínek neprojevilo pozdějšími dưsledky u žádného ze sledovaných parametrů. U odstavených selat lze prakticky využít jeho pưsobení na zlepšení užitkovosti při medikaci krmiva.

Воздействие фенобарбитала на рост поросят, адренокортикальную активность и некоторые метаболические параметры

Воздействие фенобарбитала, наблюдаемое в ходе 4 опытов на поросятах в возрасте 1-43 дня, проявилось лишь непосредственно или в процессе его подачи. Тройное внутримышечное введение дозы $12 \mathrm{мг/кг} \mathrm{в} \mathrm{возрасте} 1,3$ и 5 дней повысило относительную массу надпочечников. Пероральная подача в течение 14 дней после отьема поросят от свиноматки средней суточной дозой 4 мг/кг повысила массу печени и используемость корма. Фенобарбитал 
отличался тенденцией на повышение прироста массы тела в особенности у отъемных поросят, страдавших поносным заболеванием. При повторном венепункции он увеличил продукцию 17-гидрооксикортикостероидов ин витро при стимуляции с АСТН. В ходе всех указанных опытов концентрация кортикостериодов в кровяной плазме была несколько ниже. Фенобарбитал не оказал влияния на уровень общего протеина, мочевины, глюкозы, холестерина или неэтерифицированных жирных кислот в кровяной плазме. Динамика изменений данных параметров в течение 14 дней после отъема характеризует существенные изменения внутренней среды поросят. Фенобарбитал, видимо, может стать причиной временного повышения функции коры надпочечников, что, однако, не проявляется в повышении гормонального уровня в крови вследствие повышенной активности метабллизма гепатоцитов. Парентеральная подача фенобарбитала в новорожденный период в данных условиях не проявилась в последующих последствиях ни у одного из наблюдаемых параметров. У утьемных поросят его воздействия можно на практике использовать для повышения продуктивности при медикации кормов.

\section{References}

BENNINK, M. R. - FROBISH, R. A. - DAVIS, C. L. - CLARK, J. H. - BRODIE, B. O.: Phenobarbital metabolism in the lactating dairy cow. J. Dairy Sci., 56, 1973: 1964-1966.

BORÉUS, L. O. - JALLING, B. - KALLBERG, N.: Clinical pharmacology of phenobarbital in the neonatal period. In: Basic and therapeutic aspects of perinatal pharmacology. Ed. Mor selli P. L., Garattini S., Sereni F., New York, 1975: $331-340$.

BYERS, S. O. - FIEDMAN, M.: Phenobarbital as a hypocholesterolemic agent in the rat and rabbit. Metabolism, 25, 1976: 727-737.

CONNEY, A. H. - LEVIN, W. - JACOBSON, M. - KUNTZMAN, R.: Effects of drugs and environmental chemicals on steroid metabolism. Clin. Pharmac. Ther., 14, 1973: 727-741.

DAVIS, D. R. - YEARY, R. A.: Bilirubin binding to hepatic Y and Z protein (LIGANDIN): Tissue bilirubin concentrations in phenobarbital treated gunn rats (38466). Proc. Soc. exp. Biol. Med., 148, 1975: 9-13.

DENENBERG, V. H. - ZARROW, M. X.: Infantile stimulation, adult behaviour and adrenocortical activity. In: The post-natal development of phenotype, Ed. Kazda S., Deneberg V. H., Prague, 1970: pp. 123-132.

DVORÁK, M.: Hladiny celkového cholesterolu u selat ve vztahu ke stáří a $\mathrm{k}$ adrenokortikální aktivitě. Vet. Med., Praha, 12, 1967: 61-67.

DVORÁK, M.: Effects of corticotrophin, starvation and glucose on ascorbic acid levels in the blood plasma and liver of piglets. Nutr. Metabolism, 16, 1974: 215-222.

DVOŘ́K, M.: Adrenocortical function in piglets with good and retarded growth expressed in terms of body mass. Acta vet. Brno, 44, 1975: 323-334.

DVOŘÁK, M.: Ưčinky odlišného rưstu odstavených selat, hladovění a hormonálního působení na některé metabolické parametry v krevní plazmě. Vet. Med., Praha, 24, 1979: 301 -310.

DVOŘÁK, M. - RASZYK, J.: Účinek některých psychofarmak na hematologickou stressovou odpověd u selat. Vet. Med., Praha, 20, 1975: 689-699.

ERDÖSOVÁ, R. - JAKOUBEK, B. - KRAUS, M.: Effect of stress and diazepam treatment during infancy on corticosterone regulation and androgenic activity in adult male rats. Experientia, 31, 1975: 62 .

ERDÖSOVÁ, R. - KRAUS, M. - ŘHULKA, J.: Influence of stress and phenobarbital on corticosterone metabolism during early postnatal life of rat. Life Sci., 20, 1977: 459-466.

FERRANDO, R. - N'DIAYE, L. - GAUTIER, F. - HENRY, N.: Effets chez le caneton, de régimes renfermant du tourteau d'arachide contenant des aflatoxines en association ou non avec du DDT ou du phénobarbital comparaison avec un régime a base de soja. Rec. Méd. vét., 150, 1974: $601-606$.

FLINT, D. M. - RICHARDSON, D. P.: The effect of oral administration of sodium pheno barbitone on nitrogen balance in the rat. Proc. Nutr. Soc., 33, 1974: 21 A.

JAPUNDZIĆ, I. - JAPUNDZIĆ, M. - KNEZEVIĆ, B. - MIMIĆ-OKA, J.: The influence of phenobarbital in the glycogen concentration of rat liver. Experientia, 25, 1969: 478-479. 
KRITCHEVSKY, D. - TEPPER, S. A. - DAVIDSON, L. M. - STORY, J. A.: Influence of ketamine, phenylcyclidine, and phenobarbital on cholesterol metabolism in rats. Proc. Soc. exp. Biol. Med. 151, 1976: 445-447.

KUENZIG, W. - KAMM, J. J. - BOUBLIK, M. - BURNS, J. J.: The effect of phenobarbital on the microsomal mixed-function oxidase system and hepatic ultrastructure in the perinatal guinea pig. In: Basic and therapeutic aspects of perinatal pharmacology. Ed. Morselli P. L., Garattini S., Sereni F., New York, 1975: pp. 289-300.

LEVINE, S.: Stimulation in infancy. Scient. Am., 202, 1960: 80-86.

RAGNOT'T'I, G. - ALETTI, M. G.: The effects of phenobarbitone on protein synthesis by liver polyribosomes in fed and starved rats. Biochem. J., 146, 1975: 1-12.

RASZYK, J. - DVOŘ́K, M.: Účinek glukózy a fenobarbitalu na koncentraci 11-hydroxykortikosteroidů v krevní plazmě selat. Vet. Med., Praha, 21, 1976: 61-68.

ROSENBERG, I. H. - SOLOMONS, N. W. - SCHNEIDER, R. E.: Malabsorption asociated with diarrhoea and intestinal infections. Am. J. clin. Nutr., 30, 1977: 1248-1253.

SCHAUB, J. - FRIEDRICH-FRESKA, A.: The influence of phenobarbital on carbohydrate metabolism in developing rat liver. Europ. J. Pediat., 122, 1976:249-256.

SHORT, C. R. - MAINES, M. D. - WESTFALL, B. A.: Postnatal development of drug-metabolizing enzyme activity in liver and extrahepatic tissues in swine. Biol. Neonate, 21, 1972: $54-68$.

SMITH, S. J. - LIU, D. K. - LEONARD, T. B. - DUCEMAN, B. W. - VESELL, E. S.: Molecular biology of phenobarbital actions and interactions. Ann. N. Y. Acad. Sci., 281, 1976: $372-383$.

TAKAHASHI, K. - DAUGHDAY, W. H. - KIPNIS, D. M.: Regulation of immunoreactive growth hormone secretion in male rats. Endocrinology, 88, 1971: 909-917.

THOMAS, F. B. - RABA, N. - GREENBERGER, N. J. - SALSBUREY, D.: Effect of phenobarbital on small intestinal structure and function in the rat. J. lab. clin. Med., 80, 1972: 548-558.

TUMA, D. J. - SORRELL, M. F. - BARAK, A. J.: Hepatic and serum lipid patterns during development of phenobarbital-induced fatty livers in rats. Proc. Soc. exp. Biol. Med., 146, 1974: 953-956. 